\title{
Potential implications of interleukin-7 in chronic wound healing
}

\author{
ANNIE BARTLETT ${ }^{1,2}$, ANDREW J. SANDERS ${ }^{1}$, FIONA RUGE ${ }^{1,2}$, KEITH G. HARDING ${ }^{2}$ and WEN G. JIANG ${ }^{1}$ \\ ${ }^{1}$ Cardiff China Medical Research Collaborative (CCMRC); ${ }^{2}$ Department of Wound Healing, \\ Cardiff University School of Medicine, Cardiff CF14 4XN, UK
}

Received August 12, 2015; Accepted December 8, 2015

DOI: $10.3892 /$ etm.2016.3263

\begin{abstract}
Methods of identifying chronic wounds that will heal in a timely, coordinated fashion and those that will not, together with novel therapeutic strategies, are vital for progression in the field of wound healing. Interleukin (IL)-7 has been associated with various biological and pathological processes. The present study explored the potential role of IL-7 in wound healing. IL-7 expression levels were examined in a clinical cohort of chronic wounds using reverse transcription-quantitative polymerase chain reaction and immunohistochemical staining analysis. The impact of recombinant human IL-7 (rhIL-7) on the growth and migrational rates of HaCaT keratinocyte cells was subsequently examined using in vitro growth and electric cell-substrate impedance sensing functional assays. The mRNA expression levels of IL-7 were increased in the healed chronic wound tissue samples, compared with non-healed chronic wound tissue samples, although the difference was not statistically significant. Similarly, immunohistochemical analysis revealed a greater staining intensity of IL-7 in the healed chronic wound tissue sections compared with the non-healed tissue sections. Treatment with rhIL-7 did not affect $\mathrm{HaCaT}$ cell growth rates, but was shown to enhance cell migration, an effect that could be further enhanced through the addition of inhibitors of neuronal Wiskott-Aldrich syndrome protein and protein kinase B. The data of the present study suggest that the expression levels of IL-7 may be increased in healing chronic wounds, and thus IL-7 may have a role in this process, potentially through its effects on the cellular migration of keratinocytes.
\end{abstract}

\section{Introduction}

Wound healing is a complex and dynamic process that is essential for tissue homeostasis. In normal adult wound

Correspondence to: Professor Wen G. Jiang, Cardiff China Medical Research Collaborative (CCMRC), Cardiff University School of Medicine, Henry Wellcome Building, Heath Park Way, Cardiff CF14 4XN, UK

E-mail: jiangw@cf.ac.uk

Key words: interleukin-7, chronic wounds, keratinocyte, migration, wound healing healing, disruption to skin integrity triggers a series of coordinated events typically classified into three overlapping phases: The inflammatory phase entails recruitment of inflammatory cells into the wound; the proliferative phase involves the formation of granulation tissue and re-epithelialisation; and during the remodelling phase, the wound contracts and the scar matures (1). Chronic wounds may be defined as those that fail to progress through the reparative processes required to restore tissue integrity within three months (2). This inability to heal is associated with cellular and molecular abnormalities within the wound bed and often involves chronic inflammation (3). Chronic wounds represent a significant burden to the UK National Health Service, with an estimated cost of $>£ 1$ billion per year (4). One of the major challenges for clinicians is recognising which wounds will heal and which will become chronic; therefore, methods for early diagnosis of the non-healing wound are important for earlier and more aggressive intervention.

In 1988, a novel growth factor for precursor B cells was identified and designated lymphopoietin-1 (5). Now more commonly known as interleukin (IL)-7, its functional significance and therapeutic potential continue to be investigated. As a pleiotropic cytokine, IL-7 is involved in early B and T cell development (5-10), growth, maintenance and differentiation of thymocytes (11-14) and peripheral T-cell homeostasis (15-17). IL-7 expression has been detected in numerous types of tissue, including bone marrow (5), thymus gland $(9,12)$, liver, kidney, spleen $(8)$, intestine $(18,19)$ and skin $(6,19,20)$.

The IL-7 receptor (IL-7R) complex is a heterodimer of transmembrane proteins, the IL-7 specific $\alpha$ chain (also known as CD127) and the common $\gamma$ chain (CD132) $(21,22)$. Neither component is unique to IL-7 signalling, with the $\alpha$ chain also being utilised by thymic stromal lymphopoietin $(23,24)$ and the common $\gamma$ chain by other members of the interleukin family, including IL-2, IL-4, IL-9 and IL-15 (25-28). Although it is predominantly expressed by cells of the lymphoid lineage, IL-7R has also been detected in human endothelial cell lines (29) and several cancer cell lines, including lung, central nervous system, renal, colon, breast and skin cancer, as well haematological malignancies (30). It also exists in a soluble form that is capable of binding IL-7 in solution (21). IL-7R activation by IL-7 binding leads to dose-dependent phosphorylation of Janus kinase (JAK)-1 and JAK-3 and subsequent phosphorylation of signal transducer and activator of transcription 5, which then translocates to the nucleus to induce gene transcription $(31,32)$, as reviewed by Mazzucchelli and Durum (33). IL-7 has also 
been demonstrated to activate the phosphatidylinositol 3 kinase (PI3K)/protein kinase B (Akt) signalling pathway in murine and human thymocytes which is known to influence cell survival $(32,34,35)$; however, the exact nature of this signalling pathway is not fully understood.

Although its role in immunological development has been known for some time, studies with IL-7 transgenic mice revealed its potential to act as an oncogene in vivo and promote the malignant transformation of B and T cells (36). IL-7 has been demonstrated to affect cell growth and survival in certain haematological malignancies, including acute lymphoblastic leukaemia (37-39), cutaneous $\mathrm{T}$ cell lymphoma $(20,40,41)$, Hodgkin's disease (42), acute myeloid leukaemia (43) and chronic lymphocytic leukaemia $(39,43,44)$. IL-7 mRNA has also been identified in numerous solid organ tumours, including Warthin's tumour of the parotid gland (45), head and neck squamous cell carcinomas (46), renal cell carcinoma (47), oesophageal carcinoma (48), colorectal carcinoma (49) and breast carcinoma (19). The exact role of IL-7 in these tumours is not fully understood, however it is thought to affect lymphocytes (49); for instance, in cutaneous T-cell lymphoma, IL-7 has been shown to support the growth of malignant T-cells in the skin (21). Increased IL-7 expression in breast cancer is associated with a higher tumour grade and poorer prognostic outcome (19). This may be due to the effects of aberrant IL-7 expression on the development, growth and differentiation of breast cancer (19), the ability of IL-7 to act as a potent growth factor for breast cancer and endothelial cells (50) and/or the ability of IL-7 to stimulate lymphangiogenesis in breast cancer cells in vitro and in a mouse model $(51,52)$. These findings are concordant with analyses conducted on non-small cell lung cancer (NSCLC), in which tumours with high IL-7 expression were more advanced and more likely to have metastasised to lymph nodes, possibly due to stimulation of lymphangiogenesis (53). Postoperative survival rates were shorter in patients with higher levels of IL-7/IL-7R expression (54). Furthermore, the expression levels of IL-7 have been reported to correlate with tumour stage and the presence of lymph node metastases (54). In vitro studies have demonstrated that IL-7 stimulates lung cancer cell proliferation and increases cyclin D1 mRNA and protein expression, higher levels of which correlate with reduced survival rates in patients with NSCLC (55).

During the study of IL-7 within the fields of haematology and immunology, it was noted that murine and human normal keratinocytes express IL-7 mRNA and protein in vitro $(6,20,56)$. It appears that one function of IL-7 in skin is to promote the survival and growth of epidermal T-cells $(56,57)$. These results prompted further investigation of the role of IL-7 in inflammatory cutaneous disease, and its involvement has been suggested in atopic dermatitis (6), bullous pemphigoid (58) and cutaneous T-cell lymphoma (20). To the best of our knowledge, no reports have been published regarding a correlation between IL-7 and wound healing. Parallels have been made between the pathophysiological parameters observed in cancer biology and wound healing $(59,60)$. Given the involvement of IL-7 in inflammation and immune responses, its role in tumour development and progression and its expression by human keratinocytes, the present study investigated the effect of IL-7 on wound healing.

\section{Materials and methods}

Wound tissue cohort. Information regarding the wound tissue cohort and collection has been previously described (61). Briefly, the tissue cohort consisted of 71 chronic venous leg ulcer wound edge biopsies. The tissue samples were collected from patients attending the University of Wales wound healing clinic, following ethical approval by the South East Wales Research Ethics Committee (reference no. 09/WSE02/59). Informed written consent was provided by all patients. Samples were obtained from 71 patients between 2010 and 2013, 43\% of whom were male and 57\% were female. The mean age of these patients was 72.2 years, with a sample range of 34-99 years old. Over a 12 week follow-up of the subjects, 20 chronic wounds displayed substantial healing following conventional compression therapy and these samples were thus defined as 'healing' chronic wounds. The remaining chronic wounds that remained static or were enlarged over the 12-week period of conventional therapy were termed 'non-healing' chronic wounds for the purpose of this study. Biopsies were initially stored at $-80^{\circ} \mathrm{C}$ prior to immersion in liquid nitrogen. The tissue biopsies were sectioned using a CM1950 cryostat (Leica Microsystems Ltd., Milton Keynes, UK) at a size of $7 \mu \mathrm{m}$ for immunohistochemical analysis and $20 \mu \mathrm{m}$ for use in RNA extraction and generation of cDNA for reverse transcription-quantitative polymerase chain reaction (RT-qPCR) analysis, where multiple tissue sections were combined and homogenised using a hand held homogeniser (Cole-Parmer Instrument Co., Ltd., London, UK) in ice-cold total RNA isolation reagent (TRI) reagent ${ }^{\circledR}$ (Sigma-Aldrich Co., Ltd., Irvine, UK).

Reagents, cell lines and culture conditions. The HaCaT human keratinocyte cell line was purchased from the German Cancer Research Institute (Heidelberg, Germany). The cells were grown and maintained at $37^{\circ} \mathrm{C}, 5 \% \mathrm{CO}_{2}$ and $95 \%$ humidity in Dulbecco's modified Eagle's medium (Sigma-Aldrich Co.,Ltd.) supplemented with $10 \%$ foetal calf serum (Sigma-Aldrich Co., Ltd.) and 100X antibiotic antimycotic solution (Sigma-Aldrich Co., Ltd.; final concentration 50,000 units penicillin, $50 \mathrm{mg}$ streptomycin and $125 \mu \mathrm{g}$ amphotericin B per $500 \mathrm{ml}$ ). Recombinant human IL-7 (rhIL-7) was purchased from R\&D Systems (Abingdon, UK). The neuronal Wiskott-Aldrich syndrome protein (N-WASp) inhibitor Wiskostatin and the Akt inhibitor were purchased from Merck Millipore (Calbiochem; Watford, UK).

RNA extraction and reverse transcription. Total RNA was extracted from the homogenised sections of wound tissue and human keratinocytes using TRI reagent as described in the manufacturer's protocol (Sigma-Aldrich Co., Ltd.). Once extracted, the RNA was quantified using a spectrophotometer (WPA UV 1101; Biotech Photometer, Cambridge, UK) and RNA quantity was standardised to $250 \mathrm{ng}$ prior to reverse transcription using an iScript cDNA synthesis kit according to the manufacturer's instructions (Bio-Rad Laboratories Ltd., Hemel Hempstead, UK). Subsequently, cDNA was diluted 1:16 with nuclease-free water (Thermo Fisher Scientific, Inc., Waltham, MA, USA) and used for RT-qPCR. 
Table I. Primers used in the present study.

\begin{tabular}{lll}
\hline Primer & \multicolumn{1}{c}{ Forward (5'-3') } & \multicolumn{1}{c}{ Reverse $\left(3^{\prime}-5^{\prime}\right)$} \\
\hline IL-7 & ATTGTGATATTGAAGGTAAAGATG & ACTGAACCTGACCGTACAGCACGGAATAAA \\
GAPDH & AAGGTCATCCATGACAACTT & ACTGAACCTGACCGTACAGCCATCCACAGTCTTCTG
\end{tabular}

ACTGAACCTGACCGTACA denotes the $\mathrm{Z}$ sequence. IL, interleukin.

Immunohistochemical staining. Frozen wound tissue sections were fixed in dried acetone (Thermo Fisher Scientific, Inc.) for $15 \mathrm{~min}$, air dried for $15 \mathrm{~min}$ and then hydrated in Tris-buffered saline (TBS). The tissue sections were incubated in wash buffer containing 10\% horse serum (Sigma-Aldrich Co., Ltd.) for $1 \mathrm{~h}$ prior to incubation with monoclonal mouse anti-IL-7 primary antibody (cat. no. MAB207; R\&D Systems) diluted at a 1:100 concentration ( $2 \mu \mathrm{g} / \mathrm{ml}$ final concentration) for $1 \mathrm{~h}$ at room temperature. Subsequently, the tissue sections were washed four times in TBS buffer prior to identification of primary antibody binding using a Vectastain Elite ABC (Universal) avidin-biotin peroxidase kit in accordance with the manufacturer's protocol (Vector Laboratories, Ltd., Peterborough, UK). Visualisation of the staining intensity was obtained through the addition of 3,3'-diaminobenzidine to the tissue sections. Finally, tissue sections were counterstained with haematoxylin (Vector Laboratories, Ltd.), washed thoroughly in tap water and subjected to dehydration through a graded series (50, 70, 90, 100, 100\%) of absolute ethanol (Thermo Fisher Scientific, Inc.), prior to being cleared in xylene and mounted in DPX mounting medium (Merck Millipore). Staining intensity and localisation were visualised under a Leica DM1000 LED microscope (Leica Microsystems Ltd.). Negative controls were prepared using only the secondary universal antibody contained within the Vectastain Elite ABC (Universal) kit, in accordance with the manufacturer's protocol.

$R T-q P C R$. IL-7 expression levels were examined within the wound tissue cohort using RT-qPCR as previously described $(61,62)$. Briefly, the primer pairs were designed incorporating a complementary sequence (termed the $\mathrm{Z}$ sequence) to the Amplifluor uniprimer probe (InterGen, New York, NY, USA) into the reverse primer. RT-qPCR was undertaken using an IQ5 system (Bio-Rad Laboratories, Ltd.) and transcript copy numbers were calculated based on the quantification of a defined internal standard run on the same plate. Sample/standard cDNA was added to iQ supermix (Bio-Rad Laboratories Ltd.), target specific forward primer $(10 \mathrm{pM})$, reverse primer containing the $\mathrm{Z}$ sequence $(1 \mathrm{pM})$ and the Amplifluor uniprimer probe $(10 \mathrm{pM})$. The reaction conditions were as follows: $15 \mathrm{~min}$ at $95^{\circ} \mathrm{C}$ followed by 80 cycles of $95^{\circ} \mathrm{C}$ for $15 \mathrm{sec}, 55^{\circ} \mathrm{C}$ for $60 \mathrm{sec}$ and $72^{\circ} \mathrm{C}$ for $20 \mathrm{sec}$. Sample transcript number was subsequently normalised based on sample total expression levels of the GAPDH housekeeping gene. Full primer details are presented in Table I.

In vitro growth assay. An in vitro cell growth assay was used to examine the impact of IL-7 on HaCaT cell growth. HaCaT cells were seeded at a density of $3 \times 10^{3}$ cells/well into triplicate 96-well plates. Plates were treated, where required, with the indicated concentration of rhIL-7 (0, 1, 10 and $100 \mathrm{ng} / \mathrm{ml})$ and incubated overnight for 3 or 5 days. At each incubation point the appropriate 96 -well plate was fixed in $4 \%$ formaldehyde (v/v) and stained with $0.5 \%$ (w/v) crystal violet (Sigma-Aldrich Co., Ltd.). Plates were subsequently treated with $10 \%$ acetic acid (v/v) and placed in an ELx800 spectrophotometer plate reader (Bio-Tek Instruments Inc., Winooski, VT, USA).

Electric cell-substrate impedance sensing (ECIS) detection of cell migration. Cell migration was detected using an ECIS Z $\theta$ system (Applied Biophysics Inc., Troy, NY, USA) as described previously (63). Briefly, cells were added to 96-well electrode arrays $(96 \mathrm{~W} 1 \mathrm{E})$ in identical numbers $(80,000$ cells/well) and allowed to form a fully confluent monolayer. Following confluence, the cells were wounded through the application of $6 \mathrm{~V}$ for $30 \mathrm{sec} / w e l l$, generating a consistently sized 'wound' in the monolayer. The change in resistance was measured in each well as the cells migrated back to recolonise the electrode. This process was completed in the presence of varying concentrations of rhIL-7 (0, 1, 10 and $100 \mathrm{ng} / \mathrm{ml})$ and the rate of change of resistance was taken as an indication of cellular migration. Subsequently, $20 \mathrm{ng} / \mathrm{ml}$ of rhIL-7 was used in conjunction with a range of small molecule inhibitors to determine potential interactions between these signalling pathways on IL-7-regulated migration.

Statistical analysis. The SigmaPlot 11 statistical software package (Systat Software Inc., London, UK) was used to identify statistically significant differences between experimental groups. The data were analysed using parametric two sample, two-tailed t-test or analysis of variance (ANOVA), or non-parametric Mann-Whitney or ANOVA on RANKS depending on normality. All in vitro assays were repeated a minimum of three times. Data is presented as mean \pm standard deviation or median \pm interquartile range. $\mathrm{P}<0.05$ was considered to indicate a statistically significant result.

\section{Results}

IL-7 expression levels in healing and non-healing chronic wounds. RT-qPCR was used to compare the mRNA levels of IL-7 expression in the healing and non-healing wounds (Fig. 1). IL-7 expression levels were higher in healing chronic wounds (median expression, 0.196) compared with non-healing chronic wounds (median expression, 0.00469), although this difference was not statistically significant $(\mathrm{P}=0.229)$.

Immunohistochemical analysis was performed on 26 representative chronic wound tissue samples. A total of 


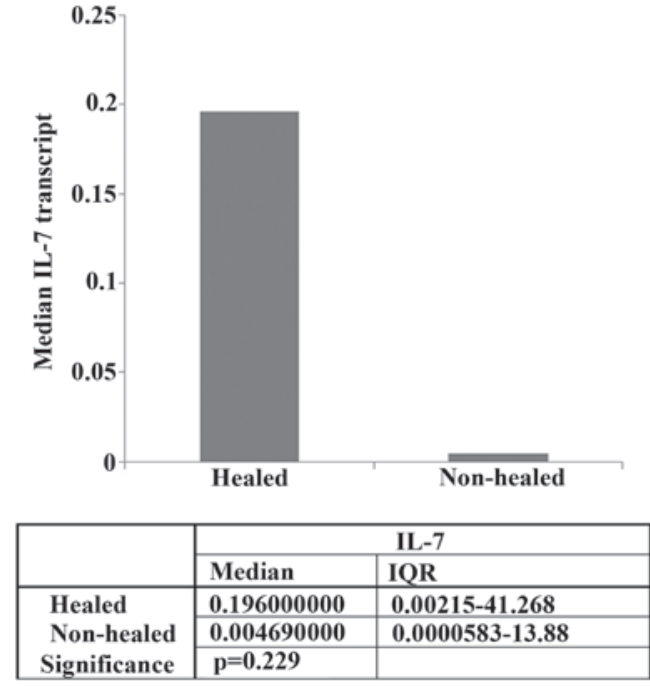

Figure 1. Reverse transcription-quantitative polymerase chain reaction analysis of IL-7 expression levels in clinical samples. Median IL-7 expression levels were increased in healing chronic wounds compared with non-healing chronic wounds, although no significant differences were observed. Descriptive data is presented in the table. IL-7, interleukin-7; IQR, interquartile range.

13 tissue samples were defined as non-healing (wound size had increased or remained the same), and the remaining 13 as healing (wounds had either completely healed or there was a decrease in size). In line with the RT-qPCR findings, IL-7 expression was generally enhanced in healing wound tissue and the majority of healing wounds (8/13) showed cytoplasmic IL-7 expression in all the layers of the epidermis. By contrast, the majority of the non-healing wounds did not show IL-7 expression (9/13), and in cases where faint staining was observed, it was localised in the basal layer (Fig. 2).

IL-7 enhances keratinocyte migration in vitro. To determine the effect of IL-7 on keratinocyte migration in vitro, $\mathrm{HaCaT}$ cells were treated with various concentrations of rhIL-7 and cell migration was analysed using the ECIS system. Following electrical wounding, $\mathrm{HaCaT}$ cells treated with rhIL-7 migrated at a faster rate compared with untreated cells (Fig. 3A) and there appeared to be a concentration-dependent gradient, with the maximum effect observed following treatment with $100 \mathrm{ng} / \mathrm{ml}$ rhIL-7. To further investigate this effect, cell migration was examined in the presence of IL-7 and numerous small molecule signalling pathway inhibitors. Concordant with the original observations, treatment of $\mathrm{HaCaT}$ cells with IL-7 $(20 \mathrm{ng} / \mathrm{ml})$ induced an increase in cell migration rates compared with the untreated controls. However, marked effects on cell migration were observed when rhIL-7 was combined with an Akt inhibitor (Fig. 3B) or N-WASp inhibitor (Fig. 3C). In both cases, the combination of rhIL-7 with the inhibitor induced an evident increase in cellular migration rate.

IL-7 does not affect keratinocyte growth in vitro. To determine the effect of IL-7 on keratinocyte growth, HaCaT cells were treated with various concentrations of rhIL-7 and cell growth was analysed over a 3-day or 5-day incubation period. No
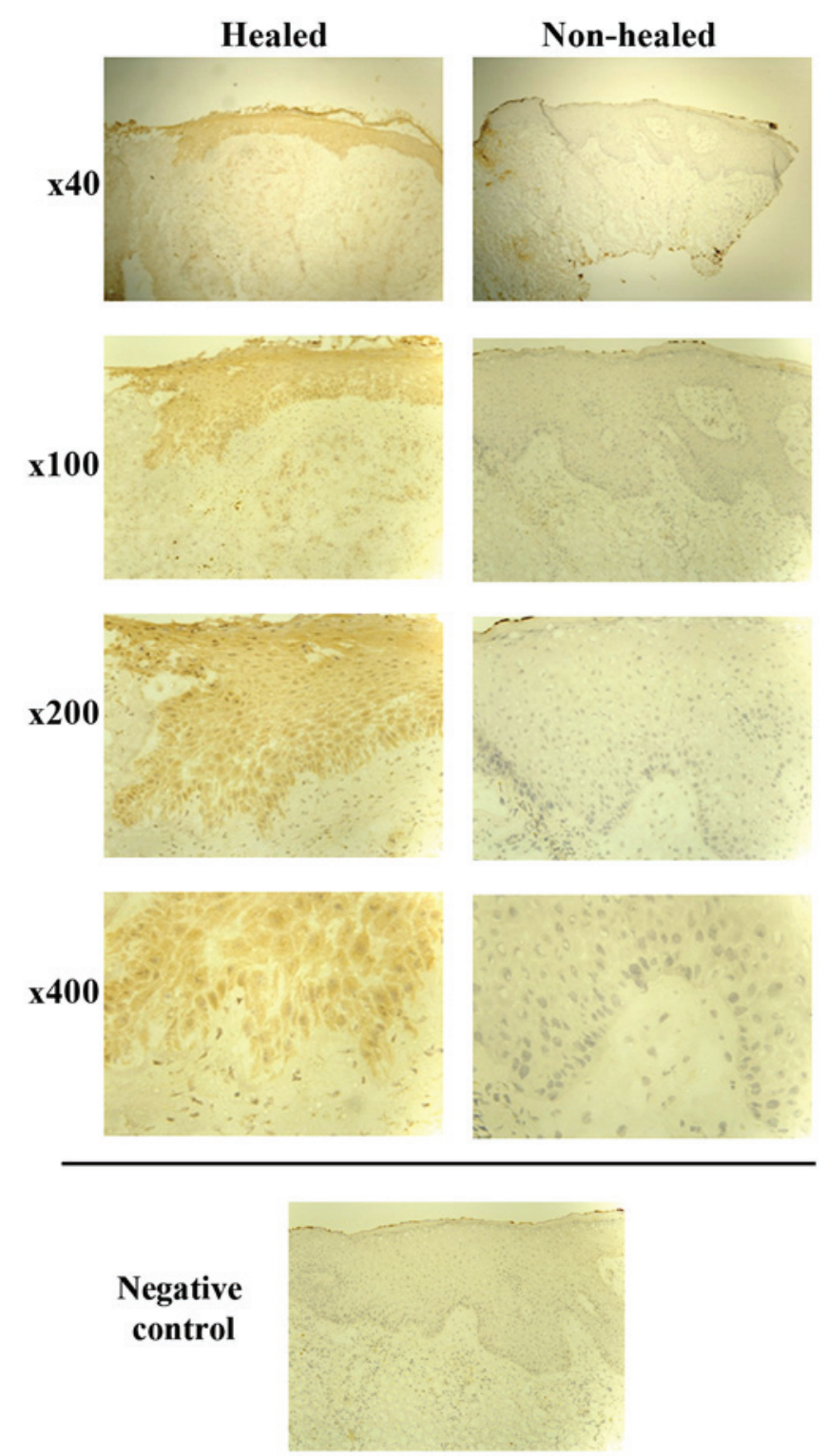

Figure 2. Immunohistochemical staining analysis of IL-7 expression in clinical tissue samples. Staining profiles demonstrated an increase in IL-7 expression in chronic-healing tissue sections compared with chronic non-healing tissue sections. Representative images are shown at $\mathrm{x} 40$, x100, x200 and x400 magnifications. Negative controls are representative of tissue sections undergoing staining with only secondary antibody. IL-7, interleukin-7.

difference in cell growth was observed between the untreated $\mathrm{HaCaT}$ controls and the cells treated with various concentrations of rhIL-7 at day 3 or 5, and there were no statistically significant differences observed between the groups at days 3 or 5 ( $\mathrm{P}>0.05$; Fig. 4 ).

\section{Discussion}

Wound healing is a complex process that requires interaction between numerous cytokines and growth factors (1). A greater understanding of these factors and interactions may provide an insight into possible treatments of chronic wounds. Therefore, the present study investigated the presence of IL-7 in healing and non-healing wounds, and its effect on keratinocytes in vitro. 


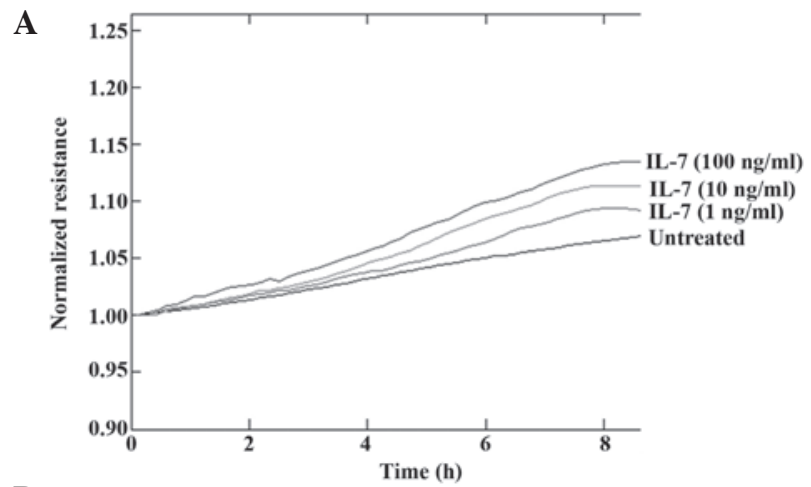

B

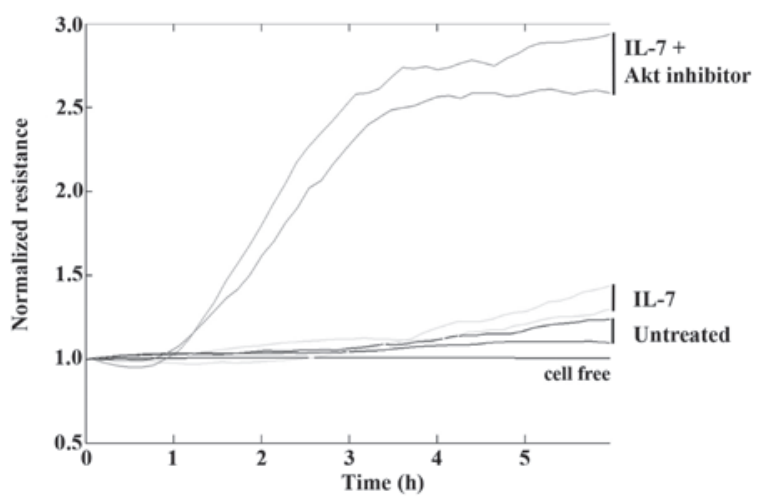

C

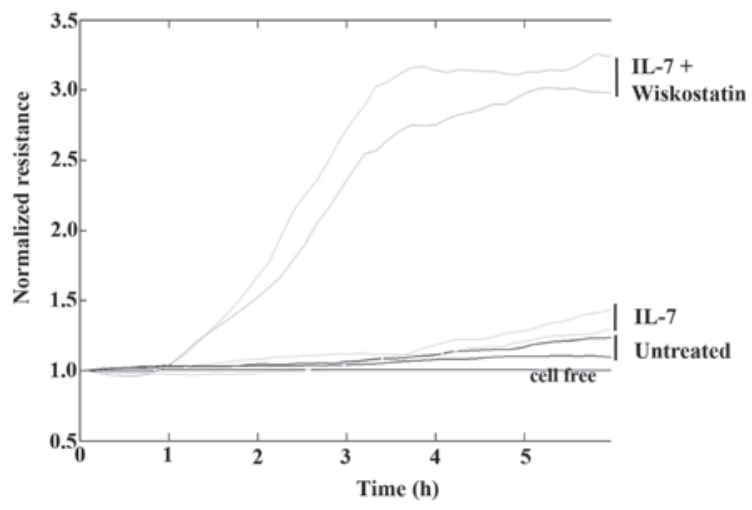

Figure 3. Electric cell substrate impedance sensing analysis of cellular migration. (A) Following electrical wounding rhIL-7 was demonstrated to have a dose-dependant effect on cellular migration. (B) Addition of the Akt inhibitor or the (C) N-WASp inhibitor wiskostatin in combination with rhIL-7 substantially enhanced the pro-migrational impact compared with rhIL-7 alone. Representative images shown. rhIL-7, recombinant human interleukin-7; Akt, protein kinase B.

IL-7 is a pleomorphic cytokine expressed in normal human keratinocytes (6), where it has been previously shown to support epidermal T-cell growth and survival $(56,57)$. It has an important role in immunological development, including involvement in early B- and T-cell development (5-10) and peripheral T-cell homeostasis (15-17). IL-7 may also act as an oncogene, stimulating malignant transformation, and cell growth and survival in haematological cancers (36-43).

The results of the present study demonstrated that IL-7 expression was higher in healing chronic wounds compared with non-healing chronic wounds, although the difference was not statistically significant. This was supported by immunohistochemical analysis, which also demonstrated that IL-7 expression was enhanced in healing chronic wounds, being expressed in all layers of the epidermis. To investigate the

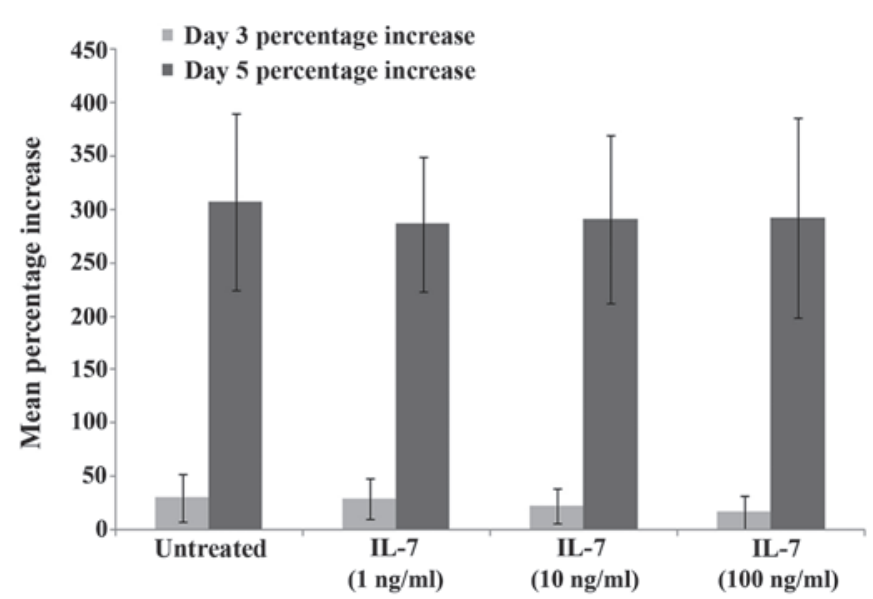

Figure 4. Cell growth rate analysis. No significant effects on growth potential were observed in the HaCaT keratinocyte cell line following the addition of rhIL-7 at 1,10 or $100 \mathrm{ng} / \mathrm{ml}$ concentrations. Data are presented as mean \pm standard error. rhIL-7, recombinant human interleukin-7.

potential underlying causes for this, the effects of rhIL-7 on human keratinocytes were analysed in vitro. Although rhIL-7 treatment led to faster keratinocyte migration, it did not affect the cell growth. Therefore, if IL-7 is affecting wound healing, it appears that the mechanism underlying its effects may occur via enhanced keratinocyte migration. Given that previous studies have demonstrated the role of IL-7 as a growth factor for epidermal T-cell growth and survival $(56,57)$, it is possible that IL-7 may be involved in the inflammatory phase of wound healing. However, a study of mRNA expression in human dermal wounds demonstrated that IL-7 mRNA expression levels initially decreased then increased in the middle and late phases of wound healing (64). These results are concordant with the data of the present study, which indicated that rhIL-7 enhanced keratinocyte migration, a process that occurs during re-epithelialisation. IL-7 was shown to be a growth factor for endothelial cells in breast cancer studies $(51,52)$; therefore, it may influence neoangiogenesis and re-vascularisation, another essential element of wound healing that occurs following the initial inflammatory phase. Since IL-7 supports cancer cell proliferation and growth $(20,50,54)$, it was initially hypothesised that it may enhance keratinocyte growth in vitro. However, no significant impact of rhIL-7 on HaCaT cell growth was observed following in vitro assays, despite the addition of high concentrations of rhIL-7.

Akt is a serine/threonine kinase involved in numerous cellular signalling pathways. It is an important mediator of numerous functions initiated by growth factor receptors that activate PI3K (65). Akt is oncogenic and contributes to the malignantbehaviour of cells, promoting cell survival,enhancing tumour cell invasion, and stimulating motility (66). IL-7 has been shown to activate the PI3K/Akt signalling pathway, promoting the survival of certain immune and cancer cells $(32,34,35,67)$. In order to evaluate the potential signalling pathways involved in the pro-migratory effect of rhIL-7 on $\mathrm{HaCaT}$ cells, two small inhibitors (Akt and N-WASp) were used to target the possible downstream signalling pathways of IL-7. Since previous studies suggested that Akt stimulates cell motility, a reasonable hypothesis appears to be that inhibiting Akt may negate the pro-migratory effect of IL-7. However, 
the opposite was shown, since a marked increase in cell migration was observed upon addition of the Akt inhibitor. A previous study demonstrated that IL-24 inhibited keratinocyte migration in vitro via an Akt-dependent signalling pathway, where addition of an Akt inhibitor reversed the inhibition of migration caused by IL-24 (61). However, the results of the current study suggested that inhibition of Akt, through small molecular inhibitors, had a pro-migratory effect on $\mathrm{HaCaT}$ cells when combined with rhIL-7 treatment. The precise mechanism underlying this phenomenon is not fully known.

Wiskott-Aldrich syndrome (WAS) is a primary immunodeficiency disorder, in which lymphocytes exhibit cytoskeletal abnormalities and a reduced response to proliferative stimuli (68). The WAS gene encodes a prolene-rich protein, termed WASp. Neural WASp (N-WASp) is a $65 \mathrm{kDa}$ protein with a $50 \%$ homology to WASp that was first identified in the bovine brain (69). Unlike WASp, which is only expressed in haematopoietic cells, N-WASp is ubiquitous (68). $\mathrm{N}-W A S p$ is required for stimulation of actin polymerization, a process necessary for cell movement and division (70). It has also been shown to stabilise intracellular adherens junctions, which maintain the endothelial barrier (71). The results of the present study demonstrated that inhibition of N-WASp caused a marked increase in the cellular migration rate with the addition of rhIL-7 in vitro. This suggested that N-WASp may have been acting to prevent migration, possibly replicating its activity in endothelial cells.

In conclusion, as chronic wounds continue to pose a significant health problem, investigations to uncover the complex processes required for prompt wound healing are ongoing. The results of the present study demonstrated that IL-7 may have a role in keratinocyte migration and may be differentially expressed between healing and non-healing chronic wounds. Further studies are required to fully establish this association and the significance of IL-7 in chronic wound healing and in the wound healing process as a whole, using different clinical cohorts with acute and chronic wound tissues. The data also suggested a potential association between IL-7 and N-WASp and Akt signalling, although additional investigation isrequired to fully understand this association and its significance to clinical wound healing.

\section{Acknowledgements}

The present study was supported by the A4B Scheme of the Welsh Government Ser Cymru, the NRN Life Sciences Research Network, and Cancer Research Wales.

\section{References}

1. Behm B, Babilas P, Landthaler M and Schreml S: Cytokines, chemokines and growth factors in wound healing. J Eur Acad Dermatol Venereol 26: 812-820, 2012

2. Werdin F, Tennenhaus M, Schaller HE and Rennekampff HO: Evidence-based management strategies for treatment of chronic wounds. Eplasty 9: e19, 2009.

3. Demidova-Rice TN, Hamblin MR and Herman IM: Acute and impaired wound healing: Pathophysiology and current methods for drug delivery, part 2: Role of growth factors in normal and pathological wound healing: Therapeutic potential and methods of delivery. Adv Skin Wound Care 25: 349-370, 2012.

4. Thomas DW and Harding KG: Wound healing. Br J Surg 89: 1203-1205, 2002.
5. Namen AE, Schmierer AE, March CJ, Overell RW, Park LS, Urdal DL and Mochizuki DY: B cell precursor growth-promoting activity. Purification and characterization of a growth factor active on lymphocyte precursors. J Exp Med 167: 988-1002, 1988.

6. Heufler C, Topar G, Grasseger A, Stanzl U, Koch F, Romani N, Namen AE and Schuler G: Interleukin 7 is produced by murine and human keratinocytes. J Exp Med 178: 1109-1114, 1993.

7. Goodwin RG, Lupton S, Schmierer A, Hjerrild KJ, Jerzy R, Clevenger W, Gillis S, Cosman D and Namen AE: Human interleukin 7: Molecular cloning and growth factor activity on human and murine B-lineage cells. Proc Natl Acad Sci USA 86: 302-306, 1989.

8. Namen AE, Lupton S, Hjerrild K, Wignall J, Mochizuki DY, Schmierer A, Mosley B, March CJ, Urdal D and Gillis S: Stimulation of B-cell progenitors by cloned murine interleukin-7. Nature 333: 571-573, 1988.

9. Sakata T, Iwagami S, Tsuruta Y, Teraoka H, Tatsumi Y, Kita Y, Nishikawa S, Takai Y and Fujiwara H: Constitutive expression of interleukin-7 mRNA and production of IL-7 by a cloned murine thymic stromal cell line. J Leukoc Biol 48: 205-212, 1990.

10. Watson JD, Morrissey PJ, Namen AE, Conlon PJ and Widmer MB: Effect of IL-7 on the growth of fetal thymocytes in culture. J Immunol 143: 1215-1222, 1989.

11. Murray R, Suda T, Wrighton N, Lee F and Zlotnik A: IL-7 is a growth and maintenance factor for mature and immature thymocyte subsets. Int Immunol 1: 526-531, 1989.

12. Wolf SS and Cohen A: Expression of cytokines and their receptors by human thymocytes and thymic stromal cells. Immunology 77: 362-368, 1992.

13. Grabstein KH, Namen AE, Shanebeck K, Voice RF, Reed SG and Widmer MB: Regulation of T cell proliferation by IL-7. J Immunol 144: 3015-3020, 1990.

14. Uckun FM, Tuel-Ahlgren L, Obuz V, Smith R, Dibirdik I, Hanson M, Langlie MC and Ledbetter JA: Interleukin 7 receptor engagement stimulates tyrosine phosphorylation, inositol phospholipid turnover, proliferation and selective differentiation to the CD4 lineage by human fetal thymocytes. Proc Natl Acad Sci USA 88: 6323-6327, 1991

15. Chazen GD, Pereira GM, LeGros G, Gillis S and Shevach EM: Interleukin 7 is a T-cell growth factor. Proc Natl Acad Sci USA 86: 5923-5927, 1989.

16. Londei M, Verhoef A, Hawrylowicz C, Groves J, De Berardinis P and Feldmann M: Interleukin 7 is a growth factor for mature human T cells. Eur J Immunol 20: 425-428, 1990.

17. Simonetta F, Gestermann N, Martinet KZ, Boniotto M, Tissières $\mathrm{P}$, Seddon $\mathrm{B}$ and Bourgeois $\mathrm{C}$ : Interleukin-7 influences FOXP3+CD4+ regulatory T cells peripheral homeostasis. PloS One 7: e36596, 2012.

18. Watanabe M, Ueno Y, Yajima T, Iwao Y, Tsuchiya M, Ishikawa H, Aiso S, Hibi T and Ishii H: Interleukin 7 is produced by human intestinal epithelial cells and regulates the proliferation of intestinal mucosal lymphocytes. J Clin Invest 95: 2945-2953, 1995.

19. Al-Rawi MA, Rmali K, Watkins G, Mansel RE and Jiang WG: Aberrant expression of interleukin-7 (IL-7) and its signalling complex in human breast cancer. Eur J Cancer 40: 494-502, 2004.

20. Dalloul A, Laroche L, Bagot M, Mossalayi MD, Fourcade C, Thacker DJ, Hogge DE, Merle-Béral H, Debré P and Schmitt C: Interleukin-7 is a growth factor for Sézary lymphoma cells. J Clin Invest 90: 1054-1060, 1992

21. Goodwin RG, Friend D, Ziegler SF, Jerzy R, Falk BA, Gimpel S, Cosman D, Dower SK, March CJ and Namen AE: Cloning of the human and murine interleukin-7 receptors: Demonstration of a soluble form and homology to a new receptor superfamily. Cell 60: 941-951, 1990.

22. Ziegler SE, Morella KK, Anderson D, Kumaki N, Leonard WJ, Cosman D and Baumann H: Reconstitution of a functional interleukin (IL)-7 receptor demonstrates that the IL-2 receptor gamma chain is required for IL-7 signal transduction. Eur J Immunol 25: 399-404, 1995.

23. Quentmeier H, Drexler HG, Fleckenstein D, Zaborski M, Armstrong A, Sims JE and Lyman SD: Cloning of human thymic stromal lymphopoietin (TSLP) and signaling mechanisms leading to proliferation. Leukemia 15: 1286-1292, 2001.

24. Pandey A, Ozaki K, Baumann H, Levin SD, Puel A, Farr AG, Ziegler SF, Leonard WJ and Lodish HF: Cloning of a receptor subunit required for signaling by thymic stromal lymphopoietin. Nat Immunol 1: 59-64, 2000 . 
25. Kondo M, Takeshita T, Higuchi M, Nakamura M, Sudo T, Nishikawa $\mathrm{S}$ and Sugamura K: Functional participation of the IL-2 receptor gamma chain in IL-7 receptor complexes. Science 263: 1453-1454, 1994.

26. Russell SM, Keegan AD, Harada N, Nakamura Y, Noguchi M, Leland P, Friedmann MC, Miyajima A, Puri RK and Paul WE: Interleukin-2 receptor gamma chain: A functional component of the interleukin-4 receptor. Science 262: 1880-1883, 1993.

27. Kimura Y, Takeshita T, Kondo M, Ishii N, Nakamura M, Van Snick J and Sugamura K: Sharing of the IL-2 receptor gamma chain with the functional IL-9 receptor complex. Int Immunol 7: 115-120, 1995.

28. Anderson DM, Kumaki S, Ahdieh M, Bertles J, Tometsko M, Loomis A, Giri J, Copeland NG, Gilbert DJ and Jenkins NA: Functional characterization of the human interleukin-15 receptor alpha chain and close linkage of IL15RA and IL2RA genes. J Biol Chem 270: 29862-29869, 1995.

29. Dus D, Krawczenko A, Załecki P, Paprocka M, Wiedłocha A Goupille C and Kieda C: IL-7 receptor is present on human microvascular endothelial cells. Immunol Lett 86: 163-168, 2003

30. Cosenza L, Gorgun G, Urbano A and Foss F: Interleukin-7 receptor expression and activation in nonhaematopoietic neoplastic cell lines. Cell Signal 14: 317-325, 2002.

31. Foxwell BM, Beadling C, Guschin D, Kerr I and Cantrell D Interleukin-7 can induce the activation of Jak 1, Jak 3 and STAT 5 proteins in murine T cells. Eur J Immunol 25: 3041-3046, 1995.

32. Pallard C, Stegmann AP, van Kleffens T, Smart F, Venkitaraman A and Spits H: Distinct roles of the phosphatidylinositol 3-kinase and STAT5 pathways in IL-7-mediated development of human thymocyte precursors. Immunity 10: 525-535, 1999.

33. Mazzucchelli R and Durum SK: Interleukin-7 receptor expression: Intelligent design. Nat Rev Immunol 7: 144-154, 2007.

34. Li WQ, Jiang Q, Khaled AR, Keller JR and Durum SK Interleukin-7 inactivates the pro-apoptotic protein Bad promoting T cell survival. J Biol Chem 279: 29160-29166, 2004.

35. Dadi HK and Roifman CM: Activation of phosphatidylinositol-3 kinase by ligation of the interleukin-7 receptor on human thymocytes. J Clin Invest 92: 1559-1563, 1993.

36. Rich BE, Campos-Torres J, Tepper RI, Moreadith RW and Leder P: Cutaneous lymphoproliferation and lymphomas in interleukin 7 transgenic mice. J Exp Med 177: 305-316, 1993

37. Touw I, Pouwels K, van Agthoven T, van Gurp R, Budel L, Hoogerbrugge H, Delwel R, Goodwin R, Namen A and Löwenberg B: Interleukin-7 is a growth factor of precursor B and T acute lymphoblastic leukemia. Blood 75: 2097-2101, 1990.

38. Eder M, Ottmann OG, Hansen-Hagge TE, Bartram CR, Gillis S Hoelzer D and Ganser A: Effects of recombinant human IL-7 on blast cell proliferation in acute lymphoblastic leukemia. Leukemia 4: 533-540, 1990.

39. Sasson SC, Smith S, Seddiki N, Zaunders JJ, Bryant A, Koelsch KK, Weatherall C, Munier ML, McGinley C, Yeung J, et al: IL-7 receptor is expressed on adult pre-B-cell acute lymphoblastic leukemia and other B-cell derived neoplasms and correlates with expression of proliferation and survival markers. Cytokine 50: 58-68, 2010.

40. Foss FM, Koc Y, Stetler-Stevenson MA, Nguyen DT, O'Brien MC Turner R and Sausville EA: Costimulation of cutaneous T-cell lymphoma cells by interleukin-7 and interleukin-2: Potential autocrine or paracrine effectors in the Sézary syndrome. J Clin Oncol 12: 326-335, 1994

41. Qin JZ, Zhang CL, Kamarashev J, Dummer R, Burg G and Dobbeling U: Interleukin-7 and interleukin-15 regulate the expression of the bcl-2 and c-myb genes in cutaneous T-cell lymphoma cells. Blood 98: 2778-2783, 2001.

42. Foss HD, Hummel M, Gottstein S, Ziemann K, Falini B, Herbst H and Stein H: Frequent expression of IL-7 gene transcripts in tumor cells of classical Hodgkin's disease. Am J Pathol 146 : 33-39, 1995.

43. Digel W, Schmid M, Heil G, Conrad P, Gillis S and Porzsolt F: Human interleukin-7 induces proliferation of neoplastic cells from chronic lymphocytic leukemia and acute leukemias. Blood 78: 753-759, 1991.

44. Yoshioka R, Shimizu S, Tachibana J, Hirose Y, Fukutoku M, Takeuchi Y, Sugai S, Takiguchi T and Konda S: Interleukin-7 (IL-7)-induced proliferation of CD8+ T-chronic lymphocytic leukemia cells. J Clin Immunol 12: 101-106, 1992.

45. Takeuchi T, Yamanouchi H, Yue Q and Ohtsuki Y: Epithelial component of lymphoid stroma-rich Warthin's tumour expresses interleukin (IL)-7. Histopathology 32: 383-384, 1998.
46. Paleri V, Pulimood A, Davies GR and Birchall MA: Interleukins 7 and 12 are expressed in head and neck squamous cancer. Clin Otolaryngol Allied Sci 26: 302-306, 2001.

47. Trinder P, Seitzer U, Gerdes J, Seliger B and Maeurer M: Constitutive and IFN-gamma regulated expression of IL-7 and IL-15 in human renal cell cancer. Int J Oncol 14: 23-31, 1999.

48. Oka M, Hirose K, Iizuka N, Aoyagi K, Yamamoto K, Abe T, Hazama S and Suzuki T: Cytokine mRNA expression patterns in human esophageal cancer cell lines. J Interferon Cytokine Res 15: 1005-1009, 1995.

49. Maeurer MJ, Walter W, Martin D, Zitvogel L, Elder E, Storkus W and Lotze MT: Interleukin-7 (IL-7) in colorectal cancer: IL-7 is produced by tissues from colorectal cancer and promotes preferential expansion of tumour infiltrating lymphocytes. Scand J Immunol 45: 182-192, 1997.

50. Al-Rawi MA, Rmali K, Mansel RE and Jiang WG: Interleukin 7 induces the growth of breast cancer cells through a wortmannin-sensitive pathway. Br J Surg 91: 61-68, 2004.

51. Al-Rawi MA, Watkins G, Mansel RE and Jiang WG: The effects of interleukin-7 on the lymphangiogenic properties of human endothelial cells. Int J Oncol 27: 721-730, 2005.

52. Al-Rawi MA, Watkins G, Mansel RE and Jiang WG: Interleukin 7 upregulates vascular endothelial growth factor D in breast cancer cells and induces lymphangiogenesis in vivo. Br J Surg 92: 305-310, 2005.

53. Ming J, Zhang Q, Qiu X and Wang E: Interleukin 7/interleukin 7 receptor induce c-Fos/c-Jun-dependent vascular endothelial growth factor-D up-regulation: A mechanism of lymphangiogenesis in lung cancer. Eur J Cancer 45: 866-873, 2009.

54. Ming J, Zhang Q, Jiang Y, Qiu X and Bai X: The expressions of IL-7 and IL-7R and the relationship between them with lymph node metastasis and prognosis in non-small cell lung cancer. Zhongguo Fei Ai Za Zhi 13: 1101-1106, 2010 (In Chinese).

55. Ming J, Jiang G, Zhang Q, Qiu X and Wang E: Interleukin-7 up-regulates cyclin D1 via activator protein-1 to promote proliferation of cell in lung cancer. Cancer Immunol Immunother 61: 79-88, 2012

56. Matsue H, Bergstresser PR and Takashima $A$ Keratinocyte-derived IL-7 serves as a growth factor for dendritic epidermal T cells in mice. J Immunol 151: 6012-6019, 1993.

57. Takashima A, Matsue H, Bergstresser PR and Ariizumi K: Interleukin-7-dependent interaction of dendritic epidermal T cells with keratinocytes. J Invest Dermatol 105 (1 Suppl): 50S-53S, 1995

58. Giacalone B, D'Auria L, Bonifati C, Ferraro C, Riccardi E, Mussi A, D'Agosto G, Cordiali-Fei P and Ameglio F: Decreased interleukin-7 and transforming growth factor-betal levels in blister fluids as compared to the respective serum levels in patients with bullous pemphigoid. Opposite behavior of TNF-alpha, interleukin-4 and interleukin-10. Exp Dermatol 7: 157-161, 1998.

59. Balkwill $\mathrm{F}$ and Mantovani A: Inflammation and cancer: Back to Virchow? Lancet 357: 539-545, 2001.

60. Dvorak HF: Tumors: Wounds that do not heal. Similarities between tumor stroma generation and wound healing. N Engl J Med 315: 1650-1659, 1986.

61. Bosanquet DC, Harding KG, Ruge F, Sanders AJ and Jiang WG: Expression of IL-24 and IL-24 receptors in human wound tissues and the biological implications of IL-24 on keratinocytes. Wound Repair Regen 20: 896-903, 2012.

62. Jiang WG, Sanders AJ, Ruge F and Harding KG: Influence of interleukin-8 (IL-8) and IL-8 receptors on the migration of human keratinocytes, the role of PLC- $\gamma$ and potential clinical implications. Exp Ther Med 3: 231-236, 2012.

63. Jiang WG, Martin TA, Lewis-Russell JM, Douglas-Jones A, Ye L and Mansel RE: Eplin-alpha expression in human breast cancer, the impact on cellular migration and clinical outcome. Mol Cancer 7: 71, 2008.

64. Palagummi S, Harbison S and Fleming R: A time-course analysis of mRNA expression during injury healing in human dermal injuries. Int J Legal Med 128: 403-414, 2014.

65. Kandel ES and Hay N: The regulation and activities of the multifunctional serine/threonine kinase Akt/PKB. Exp Cell Res 253: 210-229, 1999.

66. Grille SJ, Bellacosa A, Upson J, Klein-Szanto AJ, van Roy F, Lee-Kwon W, Donowitz M, Tsichlis PN and Larue L: The protein kinase Akt induces epithelial mesenchymal transition and promotes enhanced motility and invasiveness of squamous cell carcinoma lines. Cancer Res 63: 2172-2178, 2003. 
67. Barata JT, Silva A, Brandao JG, Nadler LM, Cardoso AA and Boussiotis VA: Activation of PI3K is indispensable for interleukin 7-mediated viability, proliferation, glucose use and growth of T cell acute lymphoblastic leukemia cells. J Exp Med 200: 659-669, 2004.

68. Ramesh N, Antón IM, Martínez-Quiles N and Geha RS: Waltzing with WASp. Trends Cell Biol 9: 15-19, 1999.

69. Miki H, Miura K and Takenawa T: N-WASp, a novel actin-depolymerizing protein, regulates the cortical cytoskeletal rearrangement in a PIP2-dependent manner downstream of tyrosine kinases. EMBO J 15: 5326-5335, 1996.
70. Rohatgi R, Ma L, Miki H, Lopez M, Kirchhausen T, Takenawa T and Kirschner MW: The interaction between N-WASp and the Arp2/3 complex links Cdc42-dependent signals to actin assembly. Cell 97: 221-231, 1999.

71. Rajput C, Kini V, Smith M, Yazbeck P, Chavez A, Schmidt T, Zhang W, Knezevic N, Komarova Y and Mehta D: Neural Wiskott-Aldrich syndrome protein (N-WASp)-mediated p120-catenin interaction with Arp2-Actin complex stabilizes endothelial adherens junctions. J Biol Chem 288: 4241-4250, 2013. 